\title{
Development of a Russian Version of the MindTime Profile Inventory: The Measurement of Past, Present, and Future Thinking in a Russian Sample
}

\author{
Ekaterina V. Zabelina $\mathrm{a}^{\mathrm{a}^{*}}$, Vincent J. Fortunato ${ }^{\mathrm{b}}$ \\ ${ }^{a}$ Chelyabinsk State University, Chelyabinsk, Russia \\ ${ }^{b}$ The MindTime Project, USA \\ *Corresponding author. E-mail: katya_k@mail.ru
}

Background. According to the theory of MindTime, as a consequence of the subjective perception of time and the ability to engage in mental time travel, three patterns of perceptual and cognitive mental activity exist: Past, Present, and Future thinking. How individuals utilize these three thinking perspectives, in combination, influences how they perceive and process information and interact with the world and with others. An English version of the MindTime Profile Inventory (MTPI), which measures Past, Present, and Future thinking, has been developed.

Objective. To develop a Russian version of the MTPI.

Design. Utilizing a non-experimental design, a Russian translation of the MTPI was administered online. Two hundred and twenty-nine Russian undergraduate students provided usable data, which was then factor analyzed to produce a viable set of items.

Results. Principal component analysis yielded a set of 38 items (14 Past; 10 Present; 14 Future) that appeared to work with a Russian population. Russian students' scores were highest on Past thinking $(\mathrm{M}=72.75)$, followed by Present thinking $(M=67.69)$, and lowest on Future thinking $(\mathrm{M}=60.86)$.

Conclusion. This study was the first step in developing a three-dimensional measure of thinking perspective for use with Russian samples. Because only 38 of the 45 translated items appeared to work well with a Russian sample, future research is needed with both larger sample sizes and working adults. Predictive validity and cross-cultural studies are also recommended.
Keywords: subjective perception of time, chronesthesia, mental time travel, MindTime, Present thinking, Past thinking, Future thinking 


\section{Introduction}

The concept of time and its relationship with mind and consciousness has been the subject of much debate throughout history, from the ancient Greeks to 17 ththrough 20th-century philosophers (e.g., Craig, Descartes, Heidegger, Husserl, Locke, McTaggart, Rousseau, Kant, Sartre) to 20th- and 21st-century psychologists, cosmologists, and physicists (e.g., Corballis, 2014; Hagelin, 1987; Jaynes, 1976; Kafatos, Tanzi, \& Chopra, 2011; King, 2014; Liljenström, 2011; Lombardo, 2011; Manning, 2014; Penrose \& Hammeroff, 2011; Perret-Clermont \& Lambolz, 2005; Suddendorf \& Corballis, 1997, 2007; Tulving, 1985a, 1985b, 2002a).

In Russia, the concept of time has been debated as well. Most often in Russian psychology, the term "time perception" is used (e.g., Kotov-Hromenko, 1961; Sokolova, 1976; Zabrodin, Borozdina, \& Mussina, 1989). Some researchers use the concept "time experience" (e.g., Golovakh \& Kronik, 1984; Tsukanov, 2000); others prefer the construct "relation to time" (e.g., Kovalyov, 1988; Nestik, 2014); still others talk about the "temporal organization" of a personality (e.g., Kublitskene, 1995; Serenkova, 1995); and, finally, the term "time perspective" is widely known (e.g., Abulkhanova \& Berezina, 2001; Frank, 1939; Nuttin, 2004). Many scientists do not differentiate among the terms, using them all to mean the same thing (e.g., Abulkhanova \& Berezina, 2001; Nestik, 2014).

It was Tulving (2002a) who first coined the term chronesthesia to describe human subjective awareness of the linear passage of time. Chronesthesia is considered to be a relatively recent evolutionary advancement of consciousness (Liljenström, 2011; Suddensorf \& Corballis, 1997, 2007) and a fundamental aspect of human experience and development (Piaget, 1954, 1955, 1969) that involves complex memory systems, self-awareness, and the ability to form higher-order complex symbolic representations of objects (Friedman, 1990; Piaget, 1969; Suddendorf \& Corballis, 1997, 2007; Tulving, 1985a, 1985b, 2002b).

Chronesthesia provided humans with the ability to dissociate mentally from the present moment, project their minds forward and backward in time, and form temporally located mental representations of themselves and of other objects of consciousness (people, places, events, thoughts, feelings, sensations). Tulving (1985a) referred to this as mental time travel. According to Suddendorf (1999; Suddendorf \& Corballis, 1997, 2007), mental time travel provided Homo sapiens with the evolutionary advantage of being able to access past experiences and knowledge stored in episodic and semantic memory, and to imagine and anticipate possible future events for long-term strategic planning. According to Tulving (1985a, 1985b, 2002b), mental time travel also provides the basis for the development of a personal identity (a "me"), which links all of the temporally based experiences that form the foundation of one's personal history. Human beings, perhaps uniquely, have developed a personal identity that is constructed from the storehouse of past memories that have been encoded and from which they have developed their body-worldbelief schemas (Stapp, 1996), which include anticipated and imagined future personal histories (Liljenström, 2011; Tulving, 1985a).

Chronesthesia and mental time travel are essential for the linguistic expression of both personal and social narratives (life scripts: Berntsen \& Bohn, 2010) and the 
dynamic social constructive process in which language evolved as a means of social interaction and collaboration (Corballis, 2011; Perrot-Clermont \& Lamboltz, 2005). Chronesthesia is implicit in narratives (e.g., in the form of plots, storylines, and temporal reference points: Bronckart, 2005; Corballis, 2011); in the temporal origin of those narratives (past, present, future); in the temporal structure embedded in the languages used to express those narratives (e.g., verb tenses); and in the temporal qualities (or qualia: see Marshall, 1909; Stout, 2008) of the concepts expressed in those narratives. Thus, the linguistic expression of human consciousness is only possible within and is inseparable from the framework of time (Ferretti \& Cosentino, 2013). Chronesthesia and mental time travel are also essential for the development of social schemas, norms, and expectations (e.g., Levine, 2006), and the development and evolution of culture and cultural artifacts (Trompenaars \& Hampden-Turner, 1997; Vale, Flynn, \& Kendal, 2012).

There is increasing evidence that how individuals utilize their episodic and semantic memory structures to engage in mental time travel forms the foundation for their emotional, perceptual, cognitive, and behavioral experiences and motivational intentions (e.g., Epstude \& Peetz, 2012; Gilead, Trope, \& Liberman, 2018; Liberman \& Trope, 1998; Trope \& Liberman, 2003, 2010, 2012). However, despite the fact that perception of time is implicit in all of human experience, little theoretical development exists, with the exception of Lewin's work $(1942,1951)$, linking human perception of time with individual differences associated with cognition, personality, and behavior, and the collective manifestation of these differences (e.g., culture). In this article, we briefly present a theory of human consciousness-the theory of MindTime - which provides a foundation for understanding individual differences. Next, we describe the development of a Russian version of the MindTime Profile Inventory, a multi-dimensional measure of a person's thinking perspective. But first, a little background.

\section{Mental Time Travel and Temporal Perspective}

In 1998, Liberman and Trope proposed that the degree of abstraction with which people form mental representations of objects will vary depending on the temporal distance of the objects of perception that are imagined. Specifically, the further out in time-or temporal distance-either into the future or into the past, that people, objects, and events are imagined, the more likely it is that abstract, general, simple, coherent, and decontextualized mental representations of those objects will be formed that convey the essences of information about those objects. Conversely, when objects of perception are perceived to exist in the present or near-term future, the more likely it is that concrete, complex, and contextualized mental representations of those objects will be formed that are oriented toward the details associated with the objects. Liberman and Trope (1998) referred to their theory of temporal perspective as construal level theory (CLT). An extensive series of studies by Liberman, Trope, and associates involving manipulations of temporal distance have supported the propositions of CLT (see Trope and Liberman, 2003, 2010, 2012 for reviews of those studies). 
Trope and Liberman (2010) extended CLT to also include spatial and social distance along with temporal distance. People, objects, and events may vary in their spatial distance, in terms of physical (geographic) location; regarding social distance, people may vary in how socially connected they are emotionally (friends, acquaintances, coworkers, neighbors, strangers). According to Liberman and Trope (2010), the greater the psychological distance between a person and an object, the more likely it is that s/he will represent it abstractly, and conversely, the more abstractly an object is represented, the greater its perceived psychological distance. Objects that are psychologically distant are represented at an abstract level of construal because that allows for better prediction of future experiences. "Forming a comprehending abstract concept enables people to mentally transcend the currently experienced object in time and space, integrating other social perspectives, and considering novel and hypothetical examples" (Trope \& Liberman, 2010, p. 442). Research has supported the propositions of the extended version of CLT theory (Fiedler, K., Jung, J., Wänke, M., \& Alexopoulos, T., 2012; Henderson, Marlone, Fujita, Rohrbach, 2011; Kalkstein, Kleinman, Wakslak, Liberman, \& Trope, 2016; Liviatan, Trope, \& Liberman, 2008; Stephan, Liberman, \& Trope, 2010, 2011; Sungar, van Koningsbruggen, \& Hartmann, 2017; Zhang, Fu-ming, Hong-yu, Shi-xiao, $\& \mathrm{Ou}, 2017)$.

It is important to note that simple manipulations of temporal, physical, and social distance, such as asking participants to adopt a past temporal perspective, a near-term temporal perspective, or a distal future temporal perspective, have been found to strongly affect how individuals mentally represent objects and events, which in turn, has been found to affect their performance on a variety of perceptual, cognitive, and social tasks.

According to the theory of MindTime (Furey \& Fortunato, 2014), three temporally based and co-dependent patterns of perceptual and cognitive mental activity exist-Past, Present, and Future thinking - which correspond with innate and subjective representations of the past, present, and future as distinct temporal realities and the symbolic and conceptual representations, concepts, and qualia (qualities: Marshall, 1909; Stout, 2008; qualis-consciousness: Clarke, 2011) that emerge from those perceived temporal realities. These, in turn, influence how people localize themselves in time, perceive and process information, and interact with the world and with others (see Figure 1).

According to the theory, Past, Present, and Future thinking represent specific evolutionary advancements of consciousness that provided evolving organisms with increasingly complex methods by which to approach positively valent stimuli and avoid negatively valent stimuli (approach and avoidance motivation). In humans, these include information-processing systems such as semantic and episodic memory systems, self-awareness, the subjective perception of time, and mental time travel.

Past thinking refers to the pattern of perceptual and cognitive mental activities that occur when individuals utilize their episodic and semantic memory systems to access and reconstruct past experiences and knowledge stored in memory, so as to evaluate and make sense of current knowledge and experiences and to facilitate sound decision making. Past thinking is reflective thinking that is oriented toward 
differentiating and dichotomizing experienced reality (making sense of and understanding the world).

Future thinking refers to the patterns of perceptual and cognitive mental activity that occur when individuals imagine future possibilities ("What if?"), perceive and imagine novel and innovative arrangements or solutions to personal and environmental challenges and opportunities. Future thinking is system-level, visionary, speculative, imaginative, and big-picture thinking oriented toward perceiving and pursuing opportunities, driving forward motion and ingenuity, and generating and exploring future possibilities.

Present thinking refers to the pattern of perceptual and cognitive mental activities that occurs when individuals form concrete, contextualized, goal-oriented mental representations of objects, and impose cognitive and behavioral control mechanisms, such as plans, structures, processes, rules, and schemas. Present thinking is functional thinking in which the lower-order properties of objects and relationships among objects are observed, and it occurs when people develop action plans, and organize the resources needed to execute those plans.

It is important to note that Past, Present, and Future thinking are all oriented toward maximizing current and future survival. The purpose of Past thinking is to maximize survival by determining the relevance, validity, and truth of information and knowledge, as well as of prevailing personal, social, and cultural schemas, expectations, and norms. The purpose of Future thinking is to maximize survival by allowing for flexible adaptation to ever-changing environmental circumstances, and by the generation of new ideas and solutions. The purpose of Present thinking is to ensure the success of motivational approach and avoidance systems, as well as to maintain and restore equilibrium with the environment after either motivational system is activated.

According to the theory, Past, Present, and Future thinking are mutually codependent, and everyone utilizes all three perspectives, but in varying degrees. For example, Past thinking allows for the reconstruction and evaluation of past experiences and knowledge stored in memory, which in turn provides the scaffolding and foundation for the generation of novel and innovative ideas and solutions by Future thinking, and the frameworks, schemas, and scripts by which Present thinking can focus on structuring the environment to increase survival. In turn, Future thinking can lead to novel and innovative ideas, methods, and solutions by which the validation processes associated with Past thinking and the planning and execution strategies associated with Present thinking can be adapted as environmental circumstances change. Similarly, Present thinking enables the integration of the products of both Past thinking and Future thinking into manifested reality, through goal setting, planning, the development of action plans, and the organization of resources to execute those plans.

According to the theory, measurable variation exists in the extent to which people utilize their Past, Present, and Future thinking; the extent to which they do so, in combination, influences how they perceive and process information and form mental representations of objects and events (cognition), form perceptual and social judgments and preferences (social cognition), develop specific goals, motivations, intentions, and preferences (motivation), communicate and interact 
with others (i.e., their personality), their temperamental, emotional, and affective dispositions (Elliot \& Thrash, 2008), and their cognitive, learning, and thinking styles (Zhang \& Sternberg, 2006).

It is important to note that thinking perspective is not the same as time perspective or time orientation. According to Lewin (1942, 1951), individuals develop their own personal psychology based on the totality of their views of and identification with their own psychological past, present, and future (see also Lasane \& O’Donnell, 2005; Lennings, 2000; Seijts, 1998; Zimbardo \& Boyd, 1999). Thus, a person's time perspective or time orientation is determined by the actual content, density, coherence, and affective tone of their thoughts (see Lasane \& O'Donnell, 2005, and Seijts, 1998 for a discussion of these characteristics). Conversely, Past, Present, and Future thinking refer to generalized patterns of perceptual and cognitive mental activity based on how episodic and semantic memory are used to access and retrieve past experiences and knowledge stored in memory, to organize, control, and structure the environment, or to imagine hypothetical future possibilities. Thus, whereas a person's time perspective is content-specific, their thinking perspective is not.

Past, Present, and Future thinking are similar to the patterns of perceptual and cognitive activity observed when temporal perspective is manipulated experimentally. Specifically, Past thinking is similar to the pattern of perceptual/cognitive mental activities that are observed when people are asked to adopt a past temporal perspective; Present thinking is similar to the pattern of perceptual/cognitive mental and behavioral activities that are observed when individuals are asked to adopt a near-term temporal perspective; and Future thinking is similar to the pattern of perceptual/cognitive mental and behavioral activities that are observed when individuals are asked to adopt a distal future temporal perspective.

In summary, Furey and Fortunato (2014) proposed that there are three codependent patterns of perceptual and cognitive mental activity based on how individuals utilize their episodic and semantic memory systems to engage in mental time travel. More importantly, they proposed that all measurable individual differences and personality traits involve the combined influence of all three thinking perspectives. ${ }^{1}$ Consequently, based on the theory, Fortunato and Furey (2009,

1 The conceptual and operational definitions of Past, Present, and Future thinking overlap both conceptually and operationality with different aspects of the Big Five personality traits of neuroticism, extraversion, openness, conscientiousness, and agreeableness (the five-factor model of personality, e.g., Costa \& McCrae, 1992a; 1992b). Although the trait approach to personality is arguably the most dominant personality approach in psychology and one largely concerned with identifying the basic dimensions of personality required to provide a systematic account of individual differences (Boyle, Matthews, \& Saklofske, 2008; Livesley \& Jang, 2005), several criticisms of trait theories have been expressed (see Livesley \& Jang, 2005; Livesley, Jang, \& Vernon, 2003). As far back as 1957, Hall and Lindsey stated that "most personality theories have been oriented toward after-the-fact explanation rather than toward the generation of new predictions concerning behavior" (p.16; as cited in Campbell, 2008). In summary, trait-based taxonomies (and current biological approaches to personality) suffer from a lack of a consistent underlying theory as to why specific traits exist as part of the make-up of the human psyche and how they enhance biological and reproductive survival (Matthews, 2008; Michalski \& Shackelford, 2008). Unlike trait taxonomies of personality, the theory of MindTime provides 
2010, 2011, 2012, 2018) developed a multi-dimensional-measure English version of thinking perspective called the MindTime Profile Inventory (MTPI). The MTPI consists of 45 items (15 Past, 15 Present, and 15 Future). The inventory has been translated into French, German, Portuguese, and Japanese. In this paper, we describe efforts to translate and verify the factor structure of a Russian version of the MTPI.

\section{Methods}

\section{Participants}

Two hundred and forty-five Russian students (65\% female) studying for a bachelor's degree, aged 18 to 23, participated in this research. An electronic link was sent to 500 Russian students currently enrolled in a bachelor's degree program. The link directed students to an online survey site (https://www.smartslices.com) from which they completed the survey.

\section{Procedure}

\section{Questionnaire}

Past, Present, and Future thinking were measured using a Russian version of the MindTime Profile Inventory (MTPI). The current English version of the MTPI from which the Russian translation was derived consists of 45 items: 15 Past thinking items, 15 Present thinking items, and 15 Future thinking items.

\section{Original Scale Development}

The MTPI had undergone several iterations since being introduced in 2009. Originally, four studies (Studies 1-4) were conducted using undergraduate students from a medium-sized university in the northwestern United States $(\mathrm{N}=293,222,614$, and 580, respectively). The MTPI items were scored using a 7-point Likert-type scale ( 1 = strongly disagree; 7 = strongly agree). A fifth study (Study 5 ) consisted of the personal and business contacts of the original authors $\left(\mathrm{N}=380 ; \mathrm{M}_{\text {age }}=43.87\right)$. A sixth study (Study 6) involved 683 graduate students from an online university based in the United States. Items for the latter two studies were scored online using a 100-point (1 to 100) rating scale, with endpoints labeled "strongly disagree" and "strongly agree".

Multiple iterative computations of principal axis structural analyses were used to determine the best set of items within and across each study. The final list of items for Studies 1-5 consisted of 7 Past items, 15 Present items, and 12 Future items. The final list of items for Study 6 consisted of 10 Past items, 14 Present items, and 10 Future items.

a theoretical foundation for understanding, in part, why individuals manifest the personality traits they do, and provides an a priori rationale for observed trait co-variation that is based on current research involving subjective perception of time, memory, and cognition, temporal perspective, the evolution of complex information-processing systems, and approach and avoidance motivation. 
The results from Studies 1, 2, and 3 were combined and reported in Fortunato and Furey $(2009,2010)$. The results from Study 4 were reported in Fortunato and Furey (2011). The results from Study 5 were not published. The results from Study 6 were reported in Fortunato and Furey (2012). Coefficient alpha estimates of reliability ranged from 0.80 to 0.86 (Past thinking), 0.91 to 0.93 (Present thinking), and 0.84 to 0.91 (Future thinking).

Since 2010, the MTPI has been available online (www.mindtime.com). During this time, additional items were tested and the data analyzed using principal axis structural analyses, resulting in a final "long" version consisting of 15 Past, 15 Present, and 15 Future items. To date, 38,136 people have taken the inventory. Most respondents live in United States. The copyright of all versions of the MTPI and all intellectual property related to MindTime are held by The MindTime Foundation, currently based in Groningen, the Netherlands.

\section{Translation into Russian}

To provide reliable results for the Russian sample, the functional equivalence of the Russian-language and English-language versions of the MTPI was established using the translation/back-translation method (Brislin, 1986). The 45item MTPI was first translated into Russian. Subsequently, the first author of this paper evaluated those items for accuracy. A reverse translation into English of all items was then conducted to ensure that the original meaning of the items was retained. The Appendix shows the English and Russian versions of all 45 items of the MTPI.

For each item, respondents were presented with the following instructions: "Please indicate your degree of agreement (higher percentage) or disagreement (lower percentage) with the following statement". To respond, respondents were able to place and then slide their cursor at any location on a 100-point bar. Clicking on the bar indicated a completed response and brought forward the next item. There were two response anchors, one at the lower end of the bar labeled $0 \%$ (Strongly disagree) and one at the upper end of the bar labeled 100\% (Strongly agree). Although the lower end of the bar was labeled as $0 \%$, there were exactly 100 possible response options, not 101.

\section{Data Analyses}

Because the MTPI was based on a theoretical model that posits three underlying and correlated factors (Past, Present, and Future thinking), principal component analysis using oblimin rotation and a fixed three-factor solution was used to analyze scores on the Russian translation of the 45 MTPI items. Items with low $(<.30)$ pattern coefficients and/or items that cross loaded (>.40 pattern coefficients) on more than one factor were deleted. (To reproduce the procedure followed by the authors of the original instrument, we also conducted principal axis analyses using oblimin rotation and a fixed three-factor solution. The final solutions from both methods were nearly identical.) After determining the best set of items, coefficient alpha estimates of reliability were computed. Scale scores were then derived by taking the statistical average for each remaining set of Past, Present, and Future items, 
respectively. Descriptive statistics (means, standard deviations, skew, and kurtosis) as well as tests of normality were also computed on the scale scores. The SPSS 24.0 statistical package was used to analyze the data.

\section{Results}

\section{Data Cleanup}

A total of 245 participants completed the survey. The data were examined visually for any anomalous patterns in individual responses. Univariate and multivariate outlier analyses were conducted and univariate histograms and bivariate scatterplots were drawn. All cases were carefully scrutinized. Sixteen cases were deleted for response style bias (e.g., scores were all 100's, all 1's, or all 50's) or for inconsistent responses (e.g., alternating high and low scores on Present items), yielding a final sample size of 229 participants. Three outliers were identified but not deleted, because no discernable pattern of response bias was observed: merely low or high scores on a particular thinking perspective.

\section{Structural Analyses}

Based on the principal components factors analyses, one Past item (Past125), five Present items (Present5, Present27, Present212, Present218, Present223), and one Future item (Future4) were deemed unsuitable for use with a Russian population and were thus deleted from the Russian version of the MTPI. Thus, the final Russian version of the MTPI consisted of 14 Past items, 10 Present items, and 10 Future items. Table 1 shows the final three-factor solution of the retained items.

As shown in Table 2, scale scores on Past, Present, and Future thinking were all statistically significantly negatively skewed based on z-score analysis $(+/-1.96$, two-tailed). The Kolmogorov-Smirnov test and Shapiro-Wilks test indicated that scores on Past, Present, and Future thinking were statistically significantly negatively skewed. Although, as we indicated above, we had examined the data for outliers and found three potential outliers, we did not delete them from the dataset. However, these might have contributed to the statistically significant skewness of the data.

Follow-up paired samples t-tests were computed on the three means. These results were all statistically significant. Scores on Past thinking differed statistically significantly from scores on both Present thinking $(\mathrm{t}(228)=4.90, \mathrm{p}<.001)$ and Future thinking $(\mathrm{t}(228)=8.69, \mathrm{p}<.001)$, and scores on Present thinking differed statistically significantly from scores on Future thinking $(\mathrm{t}(228)=5.51, \mathrm{p}<.001)$.

Pearson's Product-Moment correlations were computed on Past, Present, and Future thinking scale scores. These results are shown in Table 3. Past, Present, and Future thinking scores correlated positively and statistically significantly with each other (rPast-Present $=.567$, rPast-Future $=.193$, and rPresent-Present $=$ .369). Using only the final set of items, coefficient alpha estimates were computed. These were as follows: $\alpha=0.918$ (Past thinking), $\alpha=0.866$ (Present thinking), and $a=0.891$ (Future thinking). 
Table 1

Pattern coefficient matrix from the principal component analysis using oblimin rotation of scores on the final 38-item Russian translation of the MTPI items. The number of extracted factors was fixed at $k=3$

\begin{tabular}{|c|c|c|c|}
\hline \multirow{2}{*}{ Items } & \multicolumn{3}{|c|}{ Factors } \\
\hline & 1 & 2 & 3 \\
\hline Past20 & 0.82 & 0.05 & 0.09 \\
\hline Past122 & 0.81 & 0.02 & 0.06 \\
\hline Past21 & 0.79 & 0.00 & -0.01 \\
\hline Past15 & 0.75 & 0.07 & 0.14 \\
\hline Past109 & 0.71 & -0.03 & 0.01 \\
\hline Past113 & 0.71 & 0.01 & -0.13 \\
\hline Past13 & 0.68 & -0.10 & -0.21 \\
\hline Past102 & 0.67 & -0.01 & 0.11 \\
\hline Past19 & 0.61 & -0.05 & 0.03 \\
\hline Past104 & 0.61 & -0.04 & -0.24 \\
\hline Past12 & 0.60 & -0.06 & -0.11 \\
\hline Past17 & 0.57 & 0.05 & -0.21 \\
\hline Past121 & 0.57 & 0.14 & -0.10 \\
\hline Past37 & 0.50 & 0.25 & -0.13 \\
\hline Future2 & -0.07 & 0.75 & 0.10 \\
\hline Future103 & -0.16 & 0.74 & -0.06 \\
\hline Future9 & 0.02 & 0.70 & 0.00 \\
\hline Future29 & 0.09 & 0.70 & 0.04 \\
\hline Future1 & 0.08 & 0.67 & 0.08 \\
\hline Future201 & 0.01 & 0.66 & 0.27 \\
\hline Future13 & -0.23 & 0.66 & -0.23 \\
\hline Future101 & -0.04 & 0.64 & -0.19 \\
\hline Future5 & 0.15 & 0.61 & 0.19 \\
\hline Future14 & -0.12 & 0.61 & -0.22 \\
\hline Future3 & -0.01 & 0.60 & -0.13 \\
\hline Future10 & 0.11 & 0.55 & -0.18 \\
\hline Future20 & 0.13 & 0.50 & -0.10 \\
\hline Future204 & 0.19 & 0.41 & -0.13 \\
\hline Present3 & -0.07 & -0.01 & -0.85 \\
\hline Present 2 & -0.03 & 0.03 & -0.80 \\
\hline Present 10 & 0.03 & 0.05 & -0.71 \\
\hline Present4 & 0.03 & 0.25 & -0.57 \\
\hline Present217 & 0.21 & -0.05 & -0.56 \\
\hline Present102 & 0.04 & 0.28 & -0.55 \\
\hline Present26 & 0.17 & -0.15 & -0.55 \\
\hline Present1 & 0.39 & -0.10 & -0.49 \\
\hline Present21 & 0.02 & 0.22 & -0.46 \\
\hline Present 211 & 0.33 & 0.02 & -0.42 \\
\hline
\end{tabular}

Note. Pattern coefficients in bold are those that correspond with the items retained for Past, Present, and Future thinking, respectively 
Table 2

Descriptive statistics of the MPTI scales for the Russian sample $(N=229)$

\begin{tabular}{lccccccccccc}
\hline \multicolumn{1}{c}{ Scales } & \multirow{2}{*}{ Mean } & SD & Skew & Skew & z & K-S & S-W & Kurtosis & Kurtosis & z \\
\hline Past thinking & 72.75 & 15.78 & -0.37 & .16 & $-2.31^{*} .062^{*}$ & $.976^{*}$ & -0.51 & .32 & -1.59 \\
Present thinking & 67.79 & 17.07 & -0.48 & .16 & $-3.00^{*}$ & .053 & $.978^{*}$ & -0.14 & .32 & -0.44 \\
Future thinking & 60.86 & 16.80 & -0.38 & .16 & $-2.38^{*}$ & $.071^{*}$ & $.984^{*}$ & -0.29 & .32 & -0.91 \\
\hline
\end{tabular}

Note. $S D=$ standard deviation; $S E=$ Standard Error $;-S=$ Kolmogorov-Smirnov test of normality; $S$ - $W=$ Shapiro-Wilk test of normality. ${ }^{*} p<.05$

Table 3

Correlation coefficients between scale scores on Past, Present, and Future thinking $(N=229)$

\begin{tabular}{|c|c|c|c|}
\hline & 1 & 2 & 3 \\
\hline 1. Past thinking & $(.918)$ & & \\
\hline 2. Present thinking & $.567^{* *}$ & $(.866)$ & \\
\hline 3. Future thinking & $.193^{* *}$ & $.369^{*}$ & $(.891)$ \\
\hline
\end{tabular}

Note. Coefficient alpha estimates of reliability are in parentheses. ${ }^{* *} p<.01,2$-tailed.

\section{Discussion}

First, our findings indicated that of the 45 English MTPI items, 38 were psychometrically sound when translated into Russian and used with an undergraduate population. Moreover, similar to previous findings with American samples, scores on Past, Present, and Future thinking correlated positively with each other. According to the MindTime theory, Past, Present, and Future thinking represent three codependent and complementary constructs based on human subjective perception of time and the ability to engage in mental time travel.

Second, Past thinking was the dominant perspective of the Russian students. According to the theory of MindTime (Furey \& Fortunato, 2014), Past thinking is manifest as sensitivity to potentially negative environmental stimuli; a propensity to avoid risks; slow and deliberate thinking; principled, judicious, reflective, and thoughtful decision making; a propensity to second-guess decisions once made; a cautious, skeptical outlook on life; fair-mindedness; and a propensity to experience psychological distress, such as depression and anxiety. Future thinking scores were much lower than either Past or Present scores. According to the theory of MindTime, Future thinking is manifest as visionary, speculative, and big-picture thinking; the ability to imagine future possibilities; risk taking; a propensity to envision novel and innovative solutions or arrangements to personal and environmental challenges and intractable problems; and sensitivity toward perceiving opportunities. Future thinking involves forward motion; the constructive disruption of prevailing social schemas; and the adaptation and reinvention 
of such schemas to accelerate the pace of personal, social, technological, cultural, and spiritual evolution.

Third, mean scores of the Russian undergraduate sample on Past thinking ( $M$ $=72.25)$ and Present thinking $(M=67.79)$ were largely consistent with those of a broad-based global sample ( $\mathrm{N}=38,136$; mostly Americans) who had taken the MTPI. The Russian scores were MPast thinking $=73.02$; MPresent thinking $=$ 68.85. Conversely, scores on Future thinking for the Russian undergraduate sample $(M=60.86)$ appeared to differ from the global sample $(M=69.31)$. The difference in scores on Future thinking between the Russian sample and global sample might be indicative of cultural differences. In the United States and other Western cultures, risk taking, visionary thinking, imagining future possibilities, being open to identifying opportunities, and being generally optimistic about oneself and the future are more strongly encouraged than in the Russian population. According to Sokolinsky (1999), the tendency to engage in introspection and reflection, spiritual searching, a focus on risks but not on opportunities, as well as an orientation to collective experience, largely define the Russian national mentality, whereas American culture is more focused on individual achievements. We recommend future research in which scores on the same set of items (one set in Russian; one set in English), especially of Future thinking, are directly compared.

The Russian-language version of the MTPI will open new avenues of research to understand how Past, Present, and Future thinking are manifest within Russian culture. For example, the Russian-language MTPI might assist educators in better understanding the learning styles of their students. In organizations, the Russian-language MTPI might be useful for understanding person-job and person-organization fit among Russian employees, which has implications for the selection and placement of job candidates, leadership, and work-team effectiveness. In counseling contexts, matching therapists' or coaches' thinking perspective to those of their clients might influence the effectiveness of the client-therapist relationship

Finally, having a Russian language version of the MTPI opens up possibilities for further examining of cultural differences. Vale et al. (2012) argued that although the reconstruction of past events and knowledge stored in memory (Past thinking) provides the foundation for the ability to speculate about possible future scenarios and future needs (Future thinking), without transmission of shared mental models that encourage the development and expression of Future thinking, and the capacity to create new complex, efficient, and workable ideas and innovations that permeate the social structure, or to modify existing ideas, cultural evolution will not occur. Based on our preliminary findings, it appears that in Russian culture there might a need to develop and encourage Future thinking.

Preliminary cross-cultural data from North America, Europe, and Asia suggests that the theory of MindTime is generalizable across situations, domains, and cultures (The MindTime Foundation, 2012, 2013, 2014). However, we suggest additional research to examine cross-cultural differences in thinking perspective, particularly cultural variables that might differ across nations. If clear and distinct cross-cultural differences emerge, then by understanding and considering the dominant thinking perspective of each country, communication among representatives of two countries might lead to better results. For example, Future and 
Past thinking can be complementary elements in the interaction of representatives of two cultures, which might make it possible to solve complex problems on the international level most effectively.

\section{Conclusion}

According to the theory of MindTime, measurable differences exist in how individuals utilize their episodic and memory systems. Based on the theory, a 45-item English version - the MTPI — had previously been developed. In this study, the 45 items were translated into Russian and administered to undergraduate students. Of the 45 items, 14 Past items, 10 Present items, and 14 Future items appeared to work well with the Russian population. Further research is needed to replicate and extend these findings.

\section{Limitations}

One limitation of this study is that we could not directly assess measurement invariance between the English version of the MTPI and the Russian version of the MTPI. Another limitation was that the sample size of Russian students was not very large. A third limitation was that the data were collected from Russian undergraduate students and thus might not generalize to the Russian population. Additional research is needed in which large samples of adults from both Russia and the United States (and other countries) are administered the same 45-item MTPI, but in their own language. The data from those studies could then be compared using confirmatory factor analyses to test for different types of measurement invariance. Finally, additional research is recommended to assess the construct validity of the Russian language version the MTPI by including measures of personality traits, such as extraversion, neuroticism, openness, conscientiousness, agreeableness, optimism, and resilience, as well as measures of other individual difference variables, such as time perspective/orientation, intellectual style, and financial risk tolerance. Possible issues in generalization of results, e.g., sample size, are limited access to data.

\section{Acknowledgements}

The study was funded by RFBR, under research project No. 18-013-00201 A.

\section{References}

Addis, D.R., Wong, A.T., \& Schacter, D.L. (2007). Remembering the past and imagining the future: Common and distinct neural substrates during event construction and elaboration. Neuropsychologia, 45(7), 1363-1377. https://doi.org/10.1016/j.neuropsychologia.2006.10.016

Berntsen, D., \& Bohn, A. (2010). Remembering and forecasting: The relation between autobiographical memory and episodic future thinking. Memory \& Cognition, 38(3), 265-278. https://doi.org/10.3758/MC.38.3.265

Boyle, G.J., Matthews, G., \& Saklofske, D.H. (2008). Personality theories and models: An overview. In G. J. Boyle, G. Matthews, \& D. H. Saklofske (Eds.), The SAGE handbook of personal- 
ity theory and assessment, Vol 1: Personality theories and models (pp. 1-29). Thousand Oaks, CA: Sage. https://doi.org/10.4135/9781849200462.n1

Brislin, R.W. (1986). The wording and translation of research instruments. In W. J. Loner \& J. W. Berry (Eds.), Field methods in cross-cultural research (pp. 137-164). Beverly Hills, CA: SAGE. Bronckart, J. (2005). The temporality of discourses: A contribution to the reshaping of human actions. In A. Perret-Clermont (Ed.) Thinking time: A multidisciplinary approach. Cambridge, MA: Hogrefe \& Huber.

Buckner, R.L. (2007). Prospection and the brain. Behavioral and Brain Sciences, 30(3), 318-319. https://doi.org/10.1017/S0140525X07002038

Campbell, J.B. (2006). Modern personality theories: What have we gained? What have we lost? In G. J. Boyle, G. Matthews, \& D. H. Saklofske (Eds.), The SAGE handbook of personality theory and assessment, Vol 1: Personality theories and models (pp. 190-212). Thousand Oaks, CA: Sage Publications. https://doi.org/10.4135/9781849200462.n9

Clarke, C. J.S. (2011). What consciousness does: A quantum cosmology of mind. Cosmology, 14.

Corballis, M.C. (2011). The recursive mind: The origins of human language, thought, and civilization. Princeton, NJ: Princeton University Press.

Corballis, M.C. (2014). Mental time travel: How the mind escapes from the present. Cosmology, 18, 139-145. Retrieved from http://cosmology.com/ConsciousTime104.html

Costa,P.T., \&McCrae, R.R.(1992a).Discriminantvalidityof NEO-PIRfacetscales.Educationaland Psychological Measurement, 52(1). 229-237. https://doi.org/10.1177/001316449205200128

Costa, P. T., \& McCrae, R. R. (1992b). The five-factor model of personality and its relevance to personality disorders. Journal of Personality Disorders, 6(4), 343-359. https://doi.org/10.1521/pedi.1992.6.4.343

Elliot, A. J., \& Thrash, T. M. (2008). Approach and avoidance temperaments. In G. J. Boyle, G. Matthews, \& D. H. Saklofske (Eds.), The SAGE handbook of personality theory and assessment, Vol 1: Personality theories and models (pp. 315-334). Thousand Oaks, CA: Sage Publications. https://doi.org/10.4135/9781849200462.n15

Epstude, K., \& Peetz, J. (2012). Mental time travel: A conceptual overview of social psychological perspectives on a fundamental human capacity. European Journal of Social Psychology, 42(3), 269-275. https://doi.org/10.1002/ejsp.1867

Ferretti, F., \& Cosentino, E. (2013). Time, language and flexibility of the mind: The role of mental time travel in linguistic comprehension and production. Philosophical Psychology, 26(1), 24-46. https://doi.org/10.1080/09515089.2011.625119

Fiedler, K., Jung, J., Wänke, M., \& Alexopoulos, T. (2012). On the relations between distinct aspects of psychological distance: An ecological basis of construal-level theory. Journal of Experimental Social Psychology, 48(5), 1014-1021. https://doi-org.lopes.idm.oclc.org/10.1016/j.jesp.2012.03.013

Fortunato, V. J., \& Furey, J. T. (2009). The theory of MindTime and the relationships between thinking perspective and the Big Five personality traits. Personality and Individual Differences, 47(4), 241-246. https://doi.org/10.1016/j.paid.2009.03.006

Fortunato, V. J., \& Furey, J. T. (2010). The theory of MindTime: The relationships between thinking perspective and time perspective. Personality and Individual Differences, 48(4), 436-441. https://doi.org/10.1016/j.paid.2009.11.015

Fortunato, V. J., \& Furey, J. T. (2011). The theory of MindTime: The relationships between Future, Past, and Present thinking and psychological well-being and distress. Personality and Individual Differences, 50(1), 20-24. https://doi.org/10.1016/j.paid.2010.08.014

Fortunato, V. J., \& Furey, J. T. (2012). An examination of thinking style patterns as a function of thinking perspective profile. Personality and Individual Differences, 53(7), 849-856. https://doi.org/10.1016/j.paid.2012.06.017 
Fortunato, V. J. \& Furey, J. T. (2018). The theory of MindTime and the MindTime Profile Inventory: Item development, and reliability and construct validity evidence. The MindTime Foundation. Friedman, W. J. (1990). About time: Inventing the fourth dimension. Cambridge, MA: MIT Press. Furey, J. (1994). It is in your nature to fly. Phoenix, AZ: Humanagement, Inc.

Furey, J. T., \& Fortunato, V. J. (2014). The theory of MindTime. Cosmology, 18, 119-130. Retrieved from http://cosmology.com/ConsciousTime102.html

Gilead, M., Trope, Y. \& Liberman, N. (2018). Thinking about the future: A construal level theory perspective. In G. Oettingen \& A. T. Sevincer (Eds.) The psychology of thinking about the future (pp. 296-309). New York, NY: Guilford Press.

Hagelin, J. (1987) Is consciousness a unified field? A field theorist's perspective. Fairfield, IA: Maharishi International University of Management.

Henderson, M. D., Wakslak, C. J., Fujita, K., \& Rohrbach, J. (2011). Construal level theory and spatial distance: Implications for mental representation, judgment, and behavior. Social Psychology, 42(3), 165-173. https://doi-org.lopes.idm.oclc.org/10.1027/1864-9335/a000060

Jaynes, J. (1976). The origin of consciousness and the breakdown of the bicameral mind. Boston, MA: Houghton Mifflin.

Kafatos, M., Tanzi, R. E., \& Chopra, D. (2011). How consciousness becomes the physical universe. Journal of Cosmology, 14. Retrieved from http://journalofcosmology.com/Consciousness140.html

Kalkstein, D. A., Kleiman, T., Wakslak, C. J., Liberman, N., \& Trope, Y. (2016). Social learning across psychological distance. Journal of Personality and Social Psychology, 110(1), 1-19. https://doi-org.lopes.idm.oclc.org/10.1037/pspa0000042

Lasane, T. P., \& O'Donnell, D. A. (2005). Time orientation measurement: A conceptual approach. In A. Strathman and J. Joireman (Eds.), Understanding behavior in the context of time: Theory, research, and application (pp. 11-30). Mahwah, NJ: Lawrence Erlbaum Associates.

Lennings, C. J. (2000). The Stanford Time Perspective Inventory: An analysis of a test of temporal orientation for research in health psychology. Journal of Applied Health Behavior, 2, $40-45$.

Lewin, K. (1942). Time perspective and morale. In G. Watson (Ed.). Civilian morale. Second yearbook of the S.P.S.S.L. Boston: Houghton Mifflin.

Lewin, K. (1951). Field theory in the social sciences: Selected theoretical papers. New York: Harper.

Liberman, N., \& Trope, Y. (1998). The role of feasibility and desirability considerations in near and distant future decisions: A test of temporal construal theory. Journal of Personality and Social Psychology, 75(1), 5-18. https://doi.org/10.1037/0022-3514.75.1.5

Liljenström, H. (2011). Intention and attention in consciousness dynamics and evolution. Journal of Cosmology, 14, 4839-4847. Retrieved from http://journalofcosmology.com/Consciousness138.html

Livesley, W. J., \& Jang, K. L. (2005). Genetic contributions to personality structure. In S. Strack (Ed.), Handbook of personality and psychopathology (pp. 103-119). Hoboken, NJ: John Wiley \& Sons.

Livesley, W. J., Jang, K. L., \& Vernon, P. A. (2003). Genetic basis of personality structure. In T. Millon \& M. J. Lerner (Eds.), Handbook of psychology: Personality and social psychology (Vol. 5, pp. 59-83). Hoboken, NJ: John Wiley \& Sons. https://doi.org/10.1002/0471264385.wei0503

Liviatan, I., Trope, Y., \& Liberman, N. (2008). Interpersonal similarity as a social distance dimension: Implications for perception of others' actions. Journal of Experimental Social Psychology, 44(5), 1256-1269. https://doi.org/10.1016/j.jesp.2008.04.007

Lombardo, T. (2011). The ecological cosmology of consciousness. Journal of Cosmology, 14, 4859-4868. Retrieved from http://journalofcosmology.com/Consciousness141.html 
Manning, L. (2014). Mental time travel and the self-concept. Cosmology, 18, 402-421. Retrieved from http://cosmology.com/ConsciousTime113.html

Marshall, H. R. (1909). The time quality in relation to realness and manifoldness. In H. R. Marshall, Consciousness. New York, NY: MacMillan.

Matthews, G. (2008). Personality and information processing: A cognitive-adaptive theory. In G. J. Boyle, G. Matthews, \& D. H. Saklofske (Eds.), The SAGE handbook of personality theory and assessment, Vol 1: Personality theories and models (pp. 56-79). Thousand Oaks, CA: Sage Publications. https://doi.org/10.4135/9781849200462.n3

Michalski, R. L., \& Shackelford, T. K. (2008). Evolutionary perspectives on personality psychology. In G. J. Boyle, G. Matthews, \& D. H. Saklofske (Eds.), The SAGE handbook of personality theory and assessment, Vol 1: Personality theories and models (pp. 174-189). Thousand Oaks, CA: Sage Publications. https://doi.org/10.4135/9781849200462.n8

The MindTime Foundation $(2012,2013,2014)$. Unpublished technical reports.

Okuda, J. (2007). Prospection or projection: Neurobiological basis of stimulus-independent mental traveling. Behavioral and Brain Sciences, 30(3), 328-329. https://doi.org/10.1017/ S0140525X07002142

Okuda, J., Fujii, T., Ohtake, H., Tsukiura, T., Tanji, K., Suzuki, K., ... Yamadori, A. (2003). Thinking of the future and past: The roles of the frontal pole and the medial temporal lobes. $\mathrm{Neu}$ roImage, 19(4), 1369. https://doi.org/10.1016/S1053-8119(03)00179-4

Perret-Clermont, A., \& Lambolez, S. (2005). Time, mind, and otherness. In A. Perret-Clermont (Ed.) Thinking time: A multidisciplinary approach. Cambridge, MA: Hogrefe \& Huber.

Penrose, R., \& Hameroff, S. (2011) Consciousness in the universe: Neuroscience, quantum space-time geometry and Orch OR theory. Journal of Cosmology, 14. Retrieved from http://journalofcosmology.com/Consciousness160.html

Piaget, J. (1954). The temporal field (M. Cook, Trans.). In The construction of reality in the child (pp. 320-349). New York, NY: Basic Books. https://doi.org/10.1037/11168-004

Piaget, J. (1955). The development of time concepts in the child. In P. H. Hoch \& J. Zubin (Eds.), Psychopathology of childhood (pp. 34-44). Oxford, United Kingdom: Grune \& Stratton.

Piaget, J. (1969). The child's conception of time. London, United Kingdom: Routledge \& Kegan Paul. [Original edition: 1946: Le développement de la notion de temps chez l'enfant. Paris: Presses Universitaires de France].

Schacter, D. L., Addis, D. R., \& Buckner, R. L. (2007). Remembering the past to imagine the future: The prospective brain. Nature Reviews Neuroscience, 8(9), 657-661. https://doi. org/10.1038/nrn2213

Seijts, G. H. (1998). The importance of future time perspective in theories of work motivation. The Journal of Psychology, 132, 154-168. https://doi.org/10.1080/00223989809599156

Sokolinsky, V. M. (1999). Psikhologicheskie osnovy ekonomiki [The psychological foundations of the economy]. Moscow: Yuniti.

Stapp, H. (1996, April). Science of consciousness and the hard problem. Based on a Plenary talk at the Conference Toward a Science of Consciousness, University of Arizona, Tucson. Retrieved from http://www-physics.lbl.gov/ stapp/38621.txt

Stephan, E., Liberman, N., \& Trope, Y. (2010). Politeness and psychological distance: A construal level perspective. Journal of Personality and Social Psychology, 98(2), 268-280. https://doi. org/10.1037/a0016960

Stephan, E., Liberman, N., \& Trope, Y. (2011). The effects of time perspective and level of construal on social distance. Journal of Experimental Social Psychology, 47(2), 397-402. https://doi.org/10.1016/j.jesp.2010.11.001

Stout, G. (2008). A manual of psychology. New York, NY: Hinds, Noble, \& Eldredge. (Original work published in 1898) 
Suddendorf, T., \& Corballis, M. C. (1997). Mental time travel and the evolution of the human mind. Genetic, Social, and General Psychology Monographs, 123(2), 133-167.

Suddendorf, T., \& Corballis, M. C. (2007a). The evolution of foresight: What is mental time travel, and is it unique to humans? Behavioral and Brain Sciences, 30(3), 299-313. https://doi.org/10.1017/S0140525X07001975

Sungur, H., van Koningsbruggen, G. M., \& Hartmann, T. (2017). Psychological distance cues in online messages: Interrelatedness of probability and spatial distance. Journal of Media Psychology: Theories, Methods, and Applications. https://doi.org.lopes.idm.oclc.org/10.1027/1864-1105/a000229

Trompenaars, F., \& Hampden-Turner, C. (1997). Riding the waves of culture: Understanding cultural diversity in business. Finland: Werner Söderström Oy.

Trope, Y., \& Liberman, N. (2003). Temporal construal. Psychological Review, 110(3), 403-421. https://doi.org/10.1037/0033-295X.110.3.403

Trope, Y., \& Liberman, N. (2010). Construal-level theory of psychological distance. Psychological Review, 117(2), 440-463. https://doi.org/10.1037/a0018963

Trope, Y., \& Liberman, N. (2012). Construal level theory. In P. A. M. Van Lange, A. W. Kruglanski, \& E. T. Higgins (Eds.), Handbook of theories of social psychology., Vol. 1 (pp. 118-134). Thousand Oaks, CA: Sage Publications Ltd. https://doi-org.lopes.idm.oclc. org/10.4135/9781446249215.n7

Tulving, E. (1985a). Memory and consciousness. Canadian Psychology / Psychologie canadienne, 26(1), 1-12. https://doi.org/10.1037/h0080017

Tulving, E. (1985b). How many memory systems are there? American Psychologist, 40(4), 385-398. https://doi.org/10.1037/0003-066X.40.4.385

Tulving, E. (2002a). Chronesthesia: Conscious awareness of subjective time. In D. T. Stuss \& R. T. Knight (Eds.), Principles of frontal lobe function (pp. 311-325). New York, NY, US: Oxford University Press. https://doi.org/10.1093/acprof:oso/9780195134971.003.0020

Tulving, E. (2002b). Episodic memory: From mind to brain. Annual Review of Psychology, 53(1), 1-25. https://doi.org/10.1146/annurev.psych.53.100901.135114

Vale, G. l., Flynn, E. G., \& Kendal, R. 1. (2012). Cumulative culture and future thinking: Is mental time travel a prerequisite to cumulative cultural evolution? Learning and Motivation, 43(4), 220-230. https://doi.org/10.1016/j.lmot.2012.05.010

Zhang, H., Xu, F., Ma, H., Kong, S., \& Li, O. (2017). Effect of temporal and spatial distance on the base-rate neglect. Chinese Journal of Clinical Psychology, 25(2), 242-245. Retrieved from https://lopes.idm.oclc.org/login?url=https://search.ebscohost.com/login. aspx?direct=true $\& \mathrm{db}=$ psyh\&AN=2017-33934-010\&site=ehost-live \&scope=site

Zhang, L. F., \& Sternberg, R. J. (2006). The nature of intellectual styles. Mahway, NJ: Lawrence Erlbaum.

Zimbardo, P. G., \& Boyd, J. N. (1999). Putting time in perspective: A valid, reliable individual difference metric. Journal of Personality and Social Psychology, 77, 1271-1288. https://doi.org/10.1037/0022-3514.77.6.1271

Original manuscript received May 08, 2018

Revised manuscript accepted March 18, 2019 First published online June 15, 2019 


\section{Appendix}

The English and Russian language versions of the MindTime Profile Items.

\begin{tabular}{|c|c|c|}
\hline & English & Russian \\
\hline Past12 & I like to reason things out. & $\begin{array}{l}\text { Мне нравится до конца продумывать, как } \\
\text { сделать те или иные вещи. }\end{array}$ \\
\hline Past13 & $\begin{array}{l}\text { I like to think things through before } \\
\text { making a decision. }\end{array}$ & $\begin{array}{l}\text { Мне нравится тщательно все продумывать } \\
\text { перед тем, как принять решение. }\end{array}$ \\
\hline Past15 & $\begin{array}{l}\text { I reflect on the facts before making a } \\
\text { decision. }\end{array}$ & $\begin{array}{l}\text { Я долго размышляю над ситуацией, прежде } \\
\text { чем принять решение. }\end{array}$ \\
\hline Past17 & $\begin{array}{l}\text { I weigh the evidence before coming to } \\
\text { a conclusion. }\end{array}$ & $\begin{array}{l}\text { Я взвешиваю все факты перед тем, как сде- } \\
\text { лать вывод. }\end{array}$ \\
\hline Past19 & $\begin{array}{l}\text { Only when I have the facts and infor- } \\
\text { mation do I feel comfortable making } \\
\text { a decision. }\end{array}$ & $\begin{array}{l}\text { Я могу спокойно принимать решение, только } \\
\text { когда у меня есть все факты и информация. }\end{array}$ \\
\hline Past20 & $\begin{array}{l}\text { I gather as much information as I can } \\
\text { before making a decision. }\end{array}$ & $\begin{array}{l}\text { Я собираю как можно больше информации } \\
\text { перед тем, как принять решение. }\end{array}$ \\
\hline Past21 & $\begin{array}{l}\text { I need to verify as much information } \\
\text { as I can before making a decision. }\end{array}$ & $\begin{array}{l}\text { Я должен проверить всю возможную инфор- } \\
\text { мацию, прежде чем принять решение. }\end{array}$ \\
\hline Past37 & $\begin{array}{l}\text { I am known for validating informa- } \\
\text { tion. }\end{array}$ & $\begin{array}{l}\text { Меня знают как человека, который всегда } \\
\text { проверяет достоверность информации. }\end{array}$ \\
\hline Past102 & $\begin{array}{l}\text { I need to have proof before I commit } \\
\text { to something. }\end{array}$ & $\begin{array}{l}\text { Мне нужны веские обоснования, прежде чем } \\
\text { я соглашусь на что-либо. }\end{array}$ \\
\hline Past104 & $\begin{array}{l}\text { I tend to think things through care- } \\
\text { fully. }\end{array}$ & Я склонен тщательно все продумывать. \\
\hline Past109 & $\begin{array}{l}\text { I need to understand the risks in- } \\
\text { volved before committing to some- } \\
\text { thing. }\end{array}$ & $\begin{array}{l}\text { Мне нужно понимать все риски, прежде чем } \\
\text { согласиться на что-то. }\end{array}$ \\
\hline
\end{tabular}

Past113 I tend to analyze things thoroughly before making a decision.

Я склонен тщательно все анализировать, прежде чем принять решение.

Обычно я тщательно обдумываю все известные мне факты, чтобы понять, как они применимы к текущей ситуации.

Обычно я тщательно обдумываю все известные мне факты, прежде чем принять решение.

Если я чего-то не знаю, то я ищу дополнительную информацию, прежде чем принять решение. making a decision.

Для меня важно быть собранным (собранной).

Present1 Being organized is important to me.

Present2 People think of me as organized.

Люди думают обо мне как о собранном человеке.

Present3 People think of me as structured.

Люди думают обо мне как об организованном человеке.

Present4 People think I am best at planning and organization.

Люди думают, что планирование и организация - мои самые сильные стороны.

I thrive in environments that are Я прекрасно себя чувствую в среде, где все структурировано и упорядочено.

Present $5^{\star} \quad \begin{aligned} & \text { I thrive in environments } \\ & \text { orderly and structured }\end{aligned}$

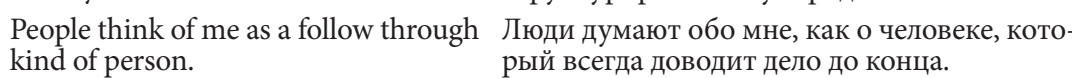

Present10 kind of person.

Я известен (известна) тем, что умею делать

Present21 I am known for getting things done. свое дело.

Present26 I am driven towards order.

Я стремлюсь к порядку. 
English

Present27* I manage others by organizing/prioritizing tasks.

Present102 I am good at organizing the resources needed to get things done.

Present211 I like to plan my daily activities.

Present $212^{*}$ I have a plan for the future.

Present217 I enjoy creating structure.

Present218* I like to be prepared for my day.

Present223* It is important for me that things go according to plan.

Future1 I like to generate ideas.

Future2 I am known for generating ideas.

Future3 I thrive in environments that are flexible and dynamic.

Future4 $^{*} \quad$ People think of me as a visionary.

Future5 I am known for invention/innovation.

Future9 I am regarded as an agent of change.

Future10 I am always on the lookout for new opportunities.

Future13 I manage others through inspiration.

Future14 People think of me as dynamic.

Future20 I am driven to explore.

Future29 People think I am best at innovation and invention.

Future101 I am open to future possibilities.

Future103 I am able to inspire others with my vision.

Future201 People think of me as imaginative.

Future204 I can easily imagine all sorts of future possibilities.
Russian

Я руковожу другими людьми, организуя задачи и определяя порядок их приоритетности.

У меня получается подготавливать ресурсы для достижения цели.

Мне нравится планировать свои повседневные дела.

У меня есть план на будущее.

Мне нравится структурировать свою деятельность.

Мне нравится быть подготовленным (подготовленной) к новому дню.

Для меня очень важно, чтобы события развивались согласно плану.

Мне нравится генерировать идеи.

Люди считают меня генератором идей.

Я уверенно чувствую себя в гибкой и динамичной обстановке.

Люди думают обо мне как о человеке со стратегическим мышлением.

Я известен (известна) изобретениями/инновациями.

Меня считают инициатором перемен.

Я всегда ищу новые возможности.

Я руковожу другими людьми, вдохновляя их. Люди думают обо мне как о динамичном человеке.

Я стремлюсь исследовать что-то новое.

Люди думают, что инновации и изобретения - мои самые сильные стороны.

Я открыт (открыта) для будущих перспектив. Я могу вдохновлять людей своими замыслами.

Люди думают обо мне как о человеке с богатым воображением.

Я легко могу представить различные варианты развития будущих перспектив.

${ }^{*}$ Items with an asterisk are not part of the final Russian language version.

Note. The English and Russian versions of the MindTime Profile Inventory are proprietary and the registered intellectual property of the MindTime Foundation. Unauthorized use or dissemination of the MindTime Profile Inventory and all related materials to any person, entity, LLC, or corporation without permission of the MindTime Foundation is prohibited. Permission to use the MindTime Profile Inventory for scientific purposes only may be requested by contacting Vincent J. Fortunato, Ph.D. at vincentfortunato@mindtime.com

To cite this article: Zabelina, E.V., Fortunato, V.J. (2019). Development of a Russian Version of the MindTime Profile Inventory: The Measurement of Past, Present, and Future Thinking in a Russian Sample. Psychology in Russia: State of the Art, 12(2), 146-164. DOI: 10.11621/ pir.2019.0211 